\title{
EFFECT OF DIFFERENT PHOTO PERIODS ON GROWTH PERFORMANCE, SURVIVAL RATE AND SKIN COLOUR OF NILE TILAPIA FINGERLINGS
}

\author{
M.A.M. Ali and A. M. I. El-Feky* \\ Department of Animal Production and Fish Resources, Faculty of Agriculture, Suez Canal \\ University, Ismailia 41522, Egypt, \\ *Corresponding author Email :(amal_elfeky@yahoo.com)
}

\section{SUMMARY}

Nile tilapia $(O$. niloticus) fingerlings averaging $15.2 \mathrm{~g}$ in weight were reared under four photoperiod regimes (24L:OD, 18L:6D, 12L: $12 \mathrm{D}$ as control and $6 \mathrm{~L}: 18 \mathrm{D})$ for 90 days to investigate their growth performance, survival rate, skin colour and proximate body composition using eight fiberglass tanks with capacity of $240 \mathrm{~L}$ water. Fish were fed a commercial diet containing $26.58 \%$ protein .Different growth measurements of tilapia were recorded every 15 days intervals. The physico-chemical analysis of water was recorded daily. The body composition and skin colour of the whole fish were determined at the stocking and at the end of the experiment. Results showed that growth performance for tilapia was significantly $(P \leq 0.05)$ increased with increasing photoperiod. No mortality occurred in any of the experimental groups. Also, the photoperiod of 24L: OD showed the best food conversion ratio, Skin luminosity $L^{*}$ and body protein and lipid content. The findings revealed that photoperiod 24L: $O D$ was more suitable for optimum growth performance, survival rate and skin colour of Nile tilapia fingerlings than any other photoperiods.

\section{Keywords: Nile tilapia, Photoperiod, Skin colour, Body composition, Performance, Survival rate.}

\section{INTRODUCTION}

Nile tilapia Oreochromis niloticus is one of the most important food fishes in the world and is prized as an aquaculture species because of, among other characteristics, the ease with which they can be bred in captivity and the wide variety of water conditions in which they will grow (Biswas et al., 2005a). The intensive culture of tilapia under controlled management systems is widely expanding to meet the increasing demands for these fishes, especially in developing countries. In this regard, the use of closed culture systems has received a considerable attention, and is becoming more common worldwide, particularly in arid areas that face shortage in fresh water or brackish water, tilapia can tolerate a wide range of water temperature, dissolved oxygen (DO), salinity, pH, light intensity and photoperiods (ElSayed and Kawanna, 2004). However, the determination of optimal environmental conditions for cultured tilapia in closed systems is essential for the maximization of its production, profitability and sustainability (Muir et al., 2000). For a long time, the influence of environmental factors on fish has been studied in respect to their effects on growth and reproduction. Fish, as ectotherms, are highly dependant on temperature. But other factors are also involved in the control of physiological functions: Salinity, $\mathrm{pH}$ and oxygen availability, the presence of 'natural toxicants', such as ammonia, are also known to play a major role on the capacity to develop and grow also Sunlight is the main natural light source. Also, (Porter et al., 1999 and Biswas et al., 2008) reported that several fish species react to longer photoperiod growth-stimulating light applications by directly improving their feed efficiency rate or reducing the incidence of sexual maturation so enabling redirection of energy from gonad development to muscle tissue and fat in the abdominal cavity. The determination of light conditions is further complicated by the fact that there may be different light requirements for different populations of the same species, as reported by (Puvanendran and Brown, 1998). Moreover, fish growth is influenced by photoperiod which stimulating the endocrine System and influence circulating growth hormone (Bjornsson, 1997). Long photoperiod has been used successfully to improve the larval, juvenile and adult growth, reproduction, gonadal maturation, locomotor activity, metabolic rates, body pigmentation and are now widely used in aquaculture to alter spawning season, manipulate maturation and stimulate growth of some species (Biswas and Takeuchi, 2002; Biswas et al., 2002; Petit et al., 2003 and Biswas et al., 2005a,b and 2006 and Freitas et al., 2009). Moreover, photoperiod acts as an artificial Zeitgeber (cue or synchronizer), regulating the daily endogenous rhythms in fish (Biswas et al., 2002). Also, light and dark alternation is generally thought to be the main synchronizer of feeding activity (Hossain et al., 1999).

\section{MATERIALS AND METHODS}

This study was conducted in tanks located indoor at fish research center, Suez Canal University Ismailia, Egypt. 


\section{Experimental fish}

Nile tilapia (Oreochromis niloticus) with average initial weight $15.2 \mathrm{~g}$ and average total length $7.25 \mathrm{~cm}$ was obtained from Fish Research Center, Suez Canal University . Fish were homogenous in size, body weights and apparently healthy. The fish were fed on the same diet used in this study for seven days prior to the start of the experiment to adapt them to the experimental conditions. Prior the experiment fish were starved for $24 \mathrm{~h}$ and their total length and body weight was measured.

\section{Experimental tanks}

Eight fiberglass tanks $(110 \times 60 \times 50 \mathrm{~cm})$ with capacity of 2401 of water for each experimental tank were used. Water in tanks was aerated by a constant supply of compressed air pump and tanks were siphoned daily to remove faeces and uneaten feed. Twenty-five percent $(25.0 \%)$ of water in each tank was renewed daily with dechlorinated tap water ( $\mathrm{Rad}$ et al ., 2006). The photoperiod in all tanks was set to 12L:12D (natural photoperiod) during the acclimation period (Biswas et al ., 2005a and Biswas et al., 2006). During this adaptation period the dead and the weak fish were eliminated daily.

\section{Experimental design}

Fish were subjected to four different photoperiod regimes $24 \mathrm{~L}: 0 \mathrm{D}, 18 \mathrm{~L}: 6 \mathrm{D}, 6 \mathrm{~L}: 18 \mathrm{D}$ artificial photoperiods and natural light-dark cycle (12L:12D) as control, each tank was covered with black cloth, control tank was kept un covered. Tilapia was stocked at a rate of 40 fish/tank for 90 days with two replicates for each photoperiod feeding on commercial diet $(26.58 \%$ protein). Light in each photoperiod tank was provided by florescent lamp (36w) suspended by about $100 \mathrm{~cm}$ over the water surface and photoperiod regimes were achieved by manual control but in 24 L:0 D photoperiod light were continuously on. Light intensity was kept constant in artificial photoperiod groups at $356 \mathrm{LX}$ through out the study and ambient light intensities in control tanks were measured in the morning at 09:00 $\mathrm{h}$ as 350-360 LX and afternoon at15:00 $\mathrm{h}$ as 100-120 LX. During the experimental period the physicochemical characteristics of water and survival were monitored daily and growth performance of tilapia was determined every 15 days. At the end of the experimental period body composition and Skin colour of the whole fish were determined.

\section{Experimental diet}

The diet used from El Bardeny Company, pellets size $2 \mathrm{~mm}$ contained $26.58 \%$ crude protein according to Stickney (1997). The diet was stored in a refrigerated area $\left(4^{\circ} \mathrm{C}\right)$ during the experimental duration to avoid the nutrients deterioration. Contents and proximate chemical analysis of the experimental diet are provided in Table (1).
Table 1. Ingredients composition and proximate analysis of the diet fed to Tilapia fish

\begin{tabular}{ll}
\hline Ingredients & $\%$ \\
\hline Fish meal & 19.76 \\
Soya bean meal & 19.76 \\
Yellow corn & 25.69 \\
Wheat bran & 25.69 \\
Fish oil & 3.95 \\
Mineral mix $*$ & 2.68 \\
Vitamin mix & 2.47 \\
Total & 100 \\
\hline
\end{tabular}

Proximate chemical analysis (\% DMB)

\begin{tabular}{ll}
\hline Ash & 15.03 \\
Crude protein & 26.58 \\
Crude fat & 13.75 \\
Crude fiber & 4.00 \\
Nitrogen-free extract & 40.64 \\
\hline
\end{tabular}

*Mineral mix (El Bardeny Company),each $0.25 \mathrm{~kg}$ contains: Iron 30,000 mg ; Manganese 60,000 mg ; Zinc $50,000 \mathrm{mg}$; Copper 4,000 mg ; Cobalt $100 \mathrm{mg}$; Iodine $300 \mathrm{mg}$ and Selenium $100 \mathrm{mg}$.

** Vitamin mix. ,each $0.25 \mathrm{~kg}$ contains: (A) 10,000,000 IU ; (D3) 2,200,000 IU; (E) 10,000 mg; (K3) 1,000 mg; (B1) $1,000 \mathrm{mg}$; (B2) 5,000 mg ; (B6)1,500 mg ; (B12) $10,000 \mathrm{mg}$; Panthotenic acid 10,000 mg; Niacin 30,000 $\mathrm{mg}$; Folic acid 1,000 mg ; Biotin 50,000 mg ; Colinechloride $600,000 \mathrm{mg}$.

\section{Feeding regime}

The daily feeding rate was $4 \%$ of the total stocking biomass during the first week of the experimental period, and there after the daily feeding rate was readjusted biweekly according to new tilapia biomass in each tank. Fish were fed twice daily (09:00 and 15:00 h) in 6 L:18 D and three time daily in other treatments. The daily feeding rate (percent of the body weight) were assigned to a particular range of wet weight according to NRC (1993). The experimental diet was offered spreading by hand for tanks.

\section{Physico-chemical analysis of water}

Water temperature was measured using oxygentemperature meter (YSI model L57) and the average was taken per 15 days. Water $\mathrm{pH}$ was measured using $\mathrm{pH}$ meter (model 56, NR 87 BB 203). The $\mathrm{pH}$ values of each tank were recorded daily in the late afternoon ( $\mathrm{Rad}$ et al., 2006). The average of $\mathrm{pH}$ values of water was recorded at15 days. The dissolved oxygen of the water was measured daily in the early morning by using oxygen-temperature meter (YSI model L57) and the average was recorded at15 days intervals during the experimental period (Pullin and McConell, 1982). The total ammonia concentration in the water was measured biweekly by using ammonia ion specific meter (HI93715) which measures the ammonia nitrogen (NH4-N) content in the water and the average was recorded every 15 days during the experimental period, un-ionized ammonia ( toxic to fish) it was calculated from total ammonia using temperature - 
pH tables( Emerson et al., 1975). Light intensity was measured at the center of water surface of each tank by a digital Lux Meter (Digital Instrument LX-101) (Freitas et al., 2009).

\section{Skin color measurements}

Skin color of the whole fish was measured along a lateral line at the level of the anterior insertion of the dorsal fin using a color reader CR-10 (Doolan et al. , 2009) to obtain representative values of L*(lightness=black 0 to white 100$), a^{*}$ (green -60 to red +60$)$ and $b^{*}$ (blue -60 to yellow +60 ) for each fish .

\section{Chemical analysis of body component:}

The crude protein content of fish body was determined by microkjeldahl technique; the fat content was determined by Soxhelt extraction with petroleum ether; the ash content was determined by burning sample in a muffle furnace at $550^{\circ} \mathrm{C}$ for $5 \mathrm{~h}$ and the moisture content and the crude fibers were determined according to the method described by the AOAC (1995).

\section{Growth parameters}

The following parameters were used to evaluate tilapia growth performance

Body weight gain $(\mathrm{WG})=\mathrm{W} 1-\mathrm{W} 0$, Average daily body weight gain (ADG): $\mathrm{ADG}=(\mathrm{W} 1-$ W0)/t(according to De-Silva and Anderson, 1995) ,Specific growth rate (\%/day): $\mathrm{SGR}=(\mathrm{Ln} \mathrm{W} 1-\mathrm{Ln}$ W0) $\times 100 /$ t) (as reported by El-Sayed and Kawanna 2004), Food conversion ratio: $\mathrm{FCR}=\mathrm{Df} /(\mathrm{W} 1-\mathrm{W} 0)$, Survival rate $(\%)$ : $\mathrm{SR}=\mathrm{Ni} \times 100 / \mathrm{N} 0$ (according to Biswas et al ., 2005a), where:W1=Final wet weight, Wo=Initial wet weight, $\mathrm{t}=$ Time interval in days, $\mathrm{Ni}=$ Number of fishes at the end, $\mathrm{N} 0=$ Number of fishes initial stocked and Df $=$ Dry feed intake.

\section{Statistical analysis}

The data obtained were analyzed by one-way ANOVA Procedure of Statistical Analysis System (SAS, 1988). Means were compared by Duncan's new multiple range test (Zar, 1996).

\section{RESULTS AND DISCUSSION}

\section{Environmental conditions}

The recorded values show a suitable environmental condition for rearing Nile tilapia fingerlings during the experiment (Table 2).Water temperature ranged from $24^{\circ} \mathrm{C}$ to $26^{\circ} \mathrm{C}$, these values were in the preferred range of temperature recorded for Nile tilapia. Changes in $\mathrm{pH}$ values of water showed that the minimum $\mathrm{pH}$ value was 7.9 and the maximum $\mathrm{pH}$ was 8.0 , this range was in the optimum values recorded for Nile tilapia. Dissolved oxygen ranged from7.2 and $7.5 \mathrm{mg} / \mathrm{l}$, this range was suitable for tilapia feeding and growth. These results are in agreement with those obtained by (El-Sayed and Kawanna, 2004; Rueda et al., 2005; Rad et al., 2006
;El-Sherif and El-Feky, 2009a and Duy et al., 2012), they showed that optimal water temperature, $\mathrm{pH}$ values and DO for optimum growth of Nile tilapia were $23-27^{\circ} \mathrm{C}, 7.9-8.2$ and 6.7 to $8 \mathrm{mg} / \mathrm{l}$, respectively. The minimal and maximal value of $\mathrm{NH}_{3}$ in the rearing period, were 0.02 and $0.08 \mathrm{mg} / \mathrm{l}$. It is clear from the tabulated data that UIA-N was suitable for growth of Nile tilapia (O. niloticus). This was in full agreement with those obtained by Saber et al. (2004), El-Sherif and El-Feky (2009a,b) and Duy et al. (2012). They showed that Nile tilapia produced the best growth rate when UIA-N ranging from 0.01 to $0.08 \mathrm{mg} / \mathrm{l}$.

\section{Growth parameters}

Mean final body weight (FBW), mean body weight gain and Specific growth rate of Nile tilapia fingerlings (Table 3) were increased as the photoperiod increased, No mortality occurred in any of the experimental groups through out the experimental period, the maximum and the minimum average weight, weight gain and SGR were (43.04 and $31.40 \mathrm{~g} / \mathrm{fish}),(28.04$ and $16.00 \mathrm{~g})$ and $(0.73$ and $0.51 \% /$ day) at photoperiods of $24 \mathrm{~L}: 0 \mathrm{D}$ and $6 \mathrm{~L}: 18$ $\mathrm{D}$, respectively and the differences between all groups were significant $(\mathrm{P} \geq 0.05)$. Also, photoperiod of $24 \mathrm{~L}: 0 \mathrm{D}$ showed the best feed conversion ratio and amount of feed consumption while the photoperiod of $6 \mathrm{~L}: 18 \mathrm{D}$ showed the boorest FCR and feed consumption, such results were in agreement with Al Jerian and Younis (1998), Biswas and Takeuchi (2002); El-Sayed and Kawanna (2004), Rad et al. (2006) and Cruz and Brown (2009). They showed that long-day photoperiods resulted in significantly higher mean final weights, SGR and FCR in tilapia than natural light regime. In the same trend, in marine fish (Skilbrei et al., 1997; Karlsen et al., 1999; Ballagh et al., 2008; Bani et al., 2009; Yue et al., 2009; Danışman-Yağcı and Yiğit, 2009; Freitas et al., 2009 and Lohne et al., 2012) reported that fish FBW, SGR, feed intake and FCR increase under long day photoperiod, it was attributed to fish being more active, and having a greater foraging activity when feed is delivered, hormonal stimulation of appetite, improvement of feed conversion efficiency and higher feed intake or suppression of sexual maturity and redirection of feed energy towards somatic growth rather than gonadal development. Moreover, Biswas et al. (2002) and Biswas et al. (2005a) attributed this to the negatively correlation between light periods and (metabolic rate and energy loss). Also, the effect of photoperiod on synchronizing an endogenous rhythm to the external environment may also require more energy in the shorter light periods, leading to a reduction of somatic fish growth; also dark period reduced the digestive performance because of the reduced activity of fish during this period. On the other hand, Crear et al. (2003), Rueda et al. (2005) and McCarron et al. (2010) noted an increased in growth 
when fish (southern rock lobsters,Jasus edwardsii, African catfish Clarias Gariepinus and European sea urchin Paracentrotus lividus ) exposed to short periods or no light, they concluded that The effect of photoperiod perhaps attributed to the species specific ( differences between fish species).

Table 2. Mean values of physico-chemical characteristic of water during rearing period (90 days) for first and second experiments Period of rearing

\begin{tabular}{|c|c|c|c|c|c|}
\hline \multirow{2}{*}{ (days) } & \multirow{2}{*}{ Water temperature $\left({ }^{\circ} \mathrm{C}\right)$} & \multirow{2}{*}{$\mathbf{p H}$} & \multirow{2}{*}{ Dissolved oxygen (mg/l) } & \multicolumn{2}{|c|}{ Ammonia (mg/l)* } \\
\hline & & & & Total ammonia & $\mathbf{N H}_{3}$ \\
\hline 15 & 24.0 & 7.9 & 7.2 & 0.50 & 0.02 \\
\hline 30 & 24.5 & 7.9 & 7.2 & 0.74 & 0.03 \\
\hline 45 & 25.1 & 8.0 & 7.3 & 0.93 & 0.05 \\
\hline 60 & 25.8 & 7.9 & 7.2 & 1.38 & 0.06 \\
\hline 75 & 25.9 & 8.0 & 7.5 & 1.39 & 0.08 \\
\hline 90 & 26.0 & 8.0 & 7.5 & 1.39 & 0.08 \\
\hline
\end{tabular}

Un - ionized ammonia (toxic to fish). It was calculated from total ammonia $\left(\mathrm{NH}^{+}+\mathrm{NH}_{3}\right)$ using temperature $-\mathrm{pH}$ equilibrium tables (Emerson et al., 1975).

Table 3. Growth performance of Nile tilapia (O.niloticus) fingerlings reared in tanks for 90 days under different photoperiod regimes

\begin{tabular}{|c|c|c|c|c|}
\hline \multirow{2}{*}{$\underbrace{\text { Treatment }}_{\text {Parameter }}$} & \multicolumn{4}{|c|}{ Different photoperiod regimes } \\
\hline & 24L:0D & 18L:6D & 12L:12D (Control) & 6L:18D \\
\hline Initial weight (g/fish) & $15 \pm 0.0$ & $15.1 \pm 0.05$ & $15.2 \pm 0.14$ & $15.4 \pm 0.15$ \\
\hline Final weight (g/fish) & $43.04 \pm 0.31^{\mathrm{a}}$ & $37.32 \pm 0.21^{b}$ & $34.72 \pm 0.12^{c}$ & $31.40 \pm 0.14^{\mathrm{d}}$ \\
\hline Body weight gain (g/fish) & $28.04 \pm 0.28^{\mathrm{a}}$ & $22.22 \pm 0.16^{b}$ & $19.52 \pm 0.1^{\mathrm{c}}$ & $16.00 \pm 0.14^{\mathrm{d}}$ \\
\hline Specific growth rate $(\% / d)$ & $1.17 \pm 0.04^{\mathrm{a}}$ & $1.01 \pm 0.04^{\mathrm{b}}$ & $0.92 \pm 0.01^{\mathrm{c}}$ & $0.79 \pm 0.02^{\mathrm{d}}$ \\
\hline Feed consumed $(g)$ & $73.12 \pm 0.07^{\mathrm{a}}$ & $68.92 \pm 0.09^{b}$ & $66.20 \pm 0.08^{\mathrm{c}}$ & $62.96 \pm 0.07^{\mathrm{d}}$ \\
\hline Feed conversion ratio & $2.60 \pm 0.03^{\mathrm{d}}$ & $3.10 \pm 0.05^{\mathrm{c}}$ & $3.39 \pm 0.04^{b}$ & $3.93 \pm 0.06^{\mathrm{a}}$ \\
\hline The condition factor $(\mathrm{CF})$ & $1.87 \pm 0.02^{\mathrm{d}}$ & $2.49 \pm 0.03^{c}$ & $2.88 \pm 0.04^{b}$ & $3.52 \pm 0.02^{\mathrm{a}}$ \\
\hline
\end{tabular}

\section{Skin colour measurements}

Table (4) showed the skin colour values of Nile tilapia fingerlings reared in tanks for 90 days at different photoperiod regimes. A thorough study of this table indicated that only luminosity $\left(\mathrm{L}^{*}\right)$ differed significantly between treatments $(\leq 0.05)$. Fish reared under 24 L:0 D conditions displayed the highest values (85.70) relative to the other three treatments, it can be concluded that skin luminosity was highest in fish reared under the longest photoperiod. On the other hand, $\mathrm{a}^{*}$ and $\mathrm{b}^{*}$ skin colour values are not significantly $(\mathrm{P} \leq 0.05)$ affected by photoperiod. Similar results were obtained by Gines et al. (2004) it could be attreputed to an adaptive effect.

\section{Proximate body composition}

The proximate body composition of $(O$. niloticus) fingerlings reared in tanks for 90 days at different photoperiod regimes (24 L:0 D , 18 L:6 D, 12L:12D and 6L:18D) at the stocking and the end of the experimental period showed in Table (5), fish exposed to $18 \mathrm{~L}: 6 \mathrm{D}$ and $24 \mathrm{~L}: 0 \mathrm{D}$ photoperiods showed a significantly $(\leq 0.05)$ higher whole body protein and lipid content than those exposed to a (12L:12D and 6L:18D) photoperiod. The poorest body protein content and lipid was recorded in (6L:18D). Also, it can be seen that moisture and fat percentages were highly inversely correlated with each other. This is in agreement with the findings of Biswas et al. (2005a), Kissil et al. (2001) and Biswas et al. (2008) who noted an increase in body protein and lipid with increasing photoperiod, This may be attributed to the protein being deposited in the body to enhance growth because the major share of growth in terms of body weight increase consists of protein growth and fish may have used lipids to mobilize energy to compensate for a greater energy demand for growth and an elevated metabolic rate.

\section{Acknowledgement}

This study is a part of Ph.D. Thesis of Amal Mohamed Ibrahim El-Feky submitted to Suez Canal University. 
Table 4. Skin colour values (Mean \pm SE) of Nile tilapia (O.niloticus) fingerlings (at the stocking and at 90 days) reared in tanks under different photoperiod regimes

\begin{tabular}{|c|c|c|c|c|c|}
\hline \multirow{3}{*}{$\begin{array}{l}\text { Skin colour } \\
\text { values }\end{array}$} & \multicolumn{5}{|c|}{ Different photoperiod regimes } \\
\hline & \multirow{2}{*}{$\begin{array}{c}\text { At zero time } \\
\text { (At the Stocking) }\end{array}$} & \multicolumn{4}{|c|}{ At 90 days } \\
\hline & & 24L:0D & 18L:6D & 12L:12D (Control) & 6L:18D \\
\hline $\mathbf{L}^{*}$ & $76.02 \pm 2.1^{\mathrm{b}}$ & $85.70 \pm 0.7^{\mathrm{a}}$ & $81.45 \pm 0.7^{\mathrm{a}}$ & $76.20 \pm 2.1^{\mathrm{b}}$ & $70.70 \pm 0.3^{\mathrm{c}}$ \\
\hline $\mathbf{a}^{*}$ & $2.14 \pm 0.23$ & $2.40 \pm 0.41$ & $2.53 \pm 0.12$ & $2.20 \pm 0.15$ & $1.73 \pm 0.49$ \\
\hline $\mathbf{b}^{*}$ & $13.90 \pm 0.74$ & $14.00 \pm 0.79$ & $13.90 \pm 0.72$ & $14.50 \pm 0.51$ & $13.43 \pm 0.48$ \\
\hline
\end{tabular}

Means with the same letter in each row are not significantly different $(\mathrm{P} \leq 0.05)$.

$L^{*}$ : Lightness $(0-100)$.

$a^{*}$ : Redness ( green -60 to red +60 ).

$b^{*}$ : Yellowness ( blue -60 to yellow+60).

Table 5. Proximate body composition (Mean \pm SE) of Nile tilapia (O.niloticus) fingerlings at the stocking and at 90days reared under different photoperiod regimes (values are expressed as dry weight basis)

\begin{tabular}{|c|c|c|c|c|c|}
\hline \multirow{3}{*}{ Parameters } & \multicolumn{5}{|c|}{ Different photoperiod regimes } \\
\hline & \multirow{2}{*}{$\begin{array}{l}\text { At zero time } \\
\text { (At the } \\
\text { Stocking) }\end{array}$} & \multicolumn{4}{|c|}{ At 90 days } \\
\hline & & 24L:0D & 18L:6D & $\begin{array}{c}\text { 12L:12D } \\
\text { (Control) }\end{array}$ & 6L:18D \\
\hline Dry weight (\%) & $19.21 \pm 0.30^{\mathrm{a}}$ & $22.93 \pm 0.16^{\mathrm{d}}$ & $22.23 \pm 0.07^{\mathrm{c}}$ & $21.90 \pm 0.05^{\mathrm{c}}$ & $21.17 \pm 0.78^{b}$ \\
\hline Crude protein (\%) & $80.56 \pm 0.22^{d}$ & $79.44 \pm 0.05^{\mathrm{a}}$ & $79.03 \pm 0.05^{\mathrm{a}}$ & $78.77 \pm 0.11^{b}$ & $78.30 \pm 0.07^{\mathrm{c}}$ \\
\hline Crude fat $(\%)$ & $7.55 \pm 0.08^{\mathrm{d}}$ & $9.41 \pm 0.22^{\mathrm{a}}$ & $9.22 \pm 0.20^{\mathrm{a}}$ & $8.62 \pm 0.11^{b}$ & $8.33 \pm 0.21^{\mathrm{c}}$ \\
\hline $\operatorname{Ash}(\%)$ & $10.84 \pm 0.07^{\mathrm{b}}$ & $10.45 \pm 0.05^{\mathrm{e}}$ & $11.02 \pm 0.11^{\mathrm{d}}$ & $11.07 \pm 0.14^{\mathrm{c}}$ & $11.33 \pm 0.07^{\mathrm{a}}$ \\
\hline
\end{tabular}

Means with the same letter in each row are not significantly different $(\mathrm{P} \leq 0.05)$.

\section{REFERENCES}

Al Jerian, A.A. and E.M. Younis, 1998. Effect of three photoperiods on the growth of tilapia fish Oreochromis aureus reared in glass tanks. Saudi Journal of Biological Sciences, 5 (2).

AOAC, 1995. Official Methods of Analysis of AOAC International. vol. I. Agricultural Chemicals; Contaminants, Drugs, 16th edition. AOAC International, Arlington, VA, USA. 1298 pp. Associations with serum testosterone, morph metrics and age during and after the breeding season. Journal of comparative biochemistry and physiology, 129: 887-895.

Ballagh, D.A., P.M Pankhurst, and D.S. Fielder, 2008. Photoperiod and feeding interval requirements of juvenile mulloway, Argyrosomus japonicus . Aquaculture, 277:52-57.

Bani, A., M. Tabarsa, B. Falahatkar and A. Banan, 2009. Effects of different photoperiods on growth, stress and haematological parameters in juvenile great sturgeon Huso huso. Aquaculture Research, 40: 1899-1907.

Biswas, A.K., M. Endo and T. Takeuchi, 2002. Effect of different photoperiod cycles metabolic rate and energy loss of both fed and unfed young tilapia (Oreochromis niloticus): Part I. Fisheries science, 68: 465- 477.

Biswas, A.K., T. Morita, G. Yoshizaki, M. Maita, and T. Takeuchi, 2005b. Control reproduction in Nile tilapia Oreochromis niloticus (L.) by photoperiod manipulation. Aquaculture 243: 229-239.'

Biswas, A. K., M. Seoka, Y. Inoue, K. Takii, and H. Kumai, 2005a. Photoperiod influences the growth, food intake, feed efficiency and digestibility of red sea bream Pagrus major. Aquaculture, 250: 666- 673.

Biswas, A.K., M. Seoka, Y. Tanaka, K. Takii, and H. Kumai, 2006. Effect of photoperiod manipulation on the growth performance and stress response of juvenile red sea bream Pagrus major. Aquaculture, 258: 350-356.

Biswas, A. K., M. Seoka, K. Ueno, A .S.K. Yong, B. K. Biswas, Y.S. Kim, K. Takii and H. Kumai, 2008. Growth performance and physiological responses in striped knifejaw, Oplegnathus fasciatus, held under different photoperiods. Aquaculture, 279: 42-46.

Biswas, A.K. and T. Takeuchi, 2002. Effect of different photoperiod cycles on metabolic rate and energy loss of both fed and unfed adult tilapia 
Oreochromis niloticus: Part II. Fisheries science 68: 543- 553 .

Bjornsson, B.T., 1997. The biology of salmon growth hormone: from daylight to dominance. Fish physiology and Biochemistry, 17: 9-24.

Boeuf, G. and P. Y. Le Bail, 1999. Does light have an influence on fish growth? Aquaculture, 177: 129-152.

Crear, B.J., P.R. Hart and C. W. Thomas, 2003. The effect of photoperiod on growth, survival, colour and activity of juvenile southern, rock lobsters Jasus edwardsii, Aquaculture Research, 34: 439444.

Cruz, E. M. V. and C. L. Brown, 2009. Influence of the photoperiod on growth rate and insulin-like growth factor-I gene expression in Nile tilapia Oreochromis niloticus. Journal of Fish Biology, 75:130-141.

Danışman-Yağc1, D. and M. Yiğit, 2009. Influence of increased photoperiods on growth, feed consumption and survival of juvenile mirror carp (Cyprinus carpio Linnaeus, 1758). Journal of Fisher ies Sciences, 3(2): 146-152.

De-Silva, S.S. and T.V. Anderson, 1995. Fish Nutrition in Aquaculture (Book). Printed in Great Britain by St. Edmundsbuzy Press, Bury St. Dmunds, Subfolk.

Doolan, B.J., M.A. Booth, G.L. Allan and P.L. Jones, 2009. Changes in skin colour and cortisol response of Australian snapper Pagrus auratus (Bloch \& Schneider, 1801) to different background colours. Aquaculture Research, 40: 542-550.

Duy, A.T., A. A. Dam and J.W. Schrama, 2012. Feed intake, growth and metabolism Nile tilapia(Oreochromis niloticus) in relation to dissolved oxygen Concentration. Aquaculture Research, 43: 730-744.

El-Sayed, A. M. and M. Kawanna, 2004. Effects of photoperiod on the performance of farmed Nile tilapia Oreochromis niloticus: I. growth, feed utilization efficiency and survival of fry and fingerlings. Aquaculture, 231:393-402.

El-Sherif, M.S. and A.M.I. El-Feky, 2009a. Performance of Nile tilapia Oreochromis niloticus fingerlings. II. Influence of different water temperatures. international journal of agriculture and biology, 11: 301-305.

El-Sherif, M.S. and A.M.I. El-Feky, $2009 \mathrm{~b}$. Performance of Nile Tilapia Oreochromis niloticus fingerlings. I. Effect of $\mathrm{pH}$. international journal of agriculture and biology, 11: 297-300.

Emerson, K., R.C. Russo, R.E. Lund and R.V. Thurston, 1975. Aqueous ammonia equilibrium calculations: Effect of $\mathrm{pH}$ and temperature. Journal of the fisheries research, 32: 2379-2383.

Freitas, L.S., R.V. Rodrigues, M. H. Okamoto, L. R. Louzada and L.A. Sampaio, 2009. Shortcommunication Effects of photoperiod on survival and growth of the marine pejerrey
Odontesthes argentinensis larvae. Aquaculture Research, 40: 252-255.

Gines, R., J.M. Afonso, A. Arguello, M. J. Zamoranoand and J. L. Lopez, 2004. The effects of long-day photoperiod on growth, body composition and skin color in immature gilthead sea bream (Sparus aurata L.). Aquaculture Research, 35: 1207- 1212.

Hossain, M., R. S. Batty, G. Haylor and M. Beveridge, 1999. Diel rhythms of feeding activity in African catfish, Clarias gariepinus (Burchell 1822). Aquaculture Research, 30: 901-905.

Karlsen, A., G.L. Taranger, R. Dahle, and B. Norberg, 1999. Effects of exercise and continuous light on early sexual maturation in farmed Atlantic cod Gadus morhu L. Proceedings of the Sixth International Symposium on the Reproductive Physiology of Fish, July 4-9, 1999. University of Bergen, Bergen, Norway, p. 499.

Lohne, P., A.K. Imsland, S. Larsen, A. Foss and K. Pittman, 2012. Interactive effect of photoperiod and temperature on the growth rates, muscle growth and feed intake in juvenile Atlantic halibut. Aquaculture Research, 43: 187-197.

McCarron, E., G. Burne, J. Kerry and G. Mouzakitis, 2010. An experimental assessment on the effects of photoperiod treatments on the somatic and gonadal growth of the juvenile European purple sea urchin Paracentrotus lividus. Aquaculture Research, 41: 1072-1081.

Muir, J., J. Van Rijn and J. Hargreaves, 2000. Production in intensive and recycle systems. In: Beveridge, M.C.M., McAndrew, B.J. (Eds.), Tilapias: Biology and Exploitation. Kluwer Academic Publishing, Great Britain, pp. 405445.

NRC (National research council), 1993. Nutrient requirements of fish. National Academy Press Washington, D.C. Petit, G.; Beauchaud. M.; Attia, J. and Buisson, B. 2003. Food intake and growth of largemouth bass (Micropterus salmoides) held under alternated light/ dark cycle (12L: 12D) or exposed to continuous light. Aquaculture, 228: 397-401.

Porter, M.J.R., N. Duncan, D. Mitchell and N.R. Bromage, 1999. The use of cage lighting to reduce plasma melatonin in Atlantic salmon (Salmo salar) and its effects on the inhibition of grilsing. Aquaculture, 176: 237-244.

Pullin, R.S.V. and L.R.H. McConell, 1982. The Biology and Culture of Tilapias. Proceedings of the International Conference on the Biology and culture of Tilapias, 2-5 September 1980 Manile, Philippines.

Puvanendran, V. and J.A. Brown, 1998. Effects of light on the foraging and growth Atlantic cod, Gadus morhua, larvae: interpopulation differences?. Marine ecology progress series, 167: 207-214. 
Rad, F., S. Bozaoğlu, S. E. Gözükara, A. Karahan, and G. Kurt, 2006. Effects of different long- day photoperiods on somatic growth and gonadal development in Nile tilapia Oreochromis niloticus L. Aquaculture 255: 292-300.

Rueda, P. A., A.T.M. Van Helmond, J.A.J. Verreth, and J.W. Schrama, 2005. Photoperiod affects growth, behaviour and stress variables in Clarias gariepinus. Journal of Fish Biology, 67: 10291039.

Saber, A. El-Shafai, Fatma, A. El-Gohary, A. N. Fayza, N. Peter van der Steen and J. G. Huub, 2004 . Chronic ammonia toxicity to duckweed-fed tilapia O. niloticus. Aquaculture, 232: 117-127.

SAS, 1988. SAS user's guide. Statistics. A. A. Ray. ed. SAS Inst., Inc., Cary, Nc., 67.

Skilbrei, O. T, T. Hansen and S. O. Stefansson, 1997. Effects of decreases in photoperiod on growth and bimodality in Atlantic salmon Salmo salar L. Aquaculture Research, 28:43- 49.
Stickney, R.R., 1997. Tilapia nutrition, Feeds and Feeding. In: Tilapia Culture in the Americas, Eds.B.A. Costa-Pierce and J.E. Rakocy. Vol.1 World Aquaculture Society, Baton Rouge, Louisiana.

Yue, C.F., T.T. Wang, Y.F. Wang and Y. Peng, 2009. Effect of combined photoperiod, water calcium concentration and $\mathrm{pH}$ on survival, growth, and molting of juvenile crayfish (Procambarus clarkii ) cultured under laboratory conditions Cai . Aquaculture Research, 40: 12431250 .

Zar, J.H., 1996. Biostatistical Analysis. Prentice Hall, Upper Saddle River, $\mathrm{Nj}$, USA.

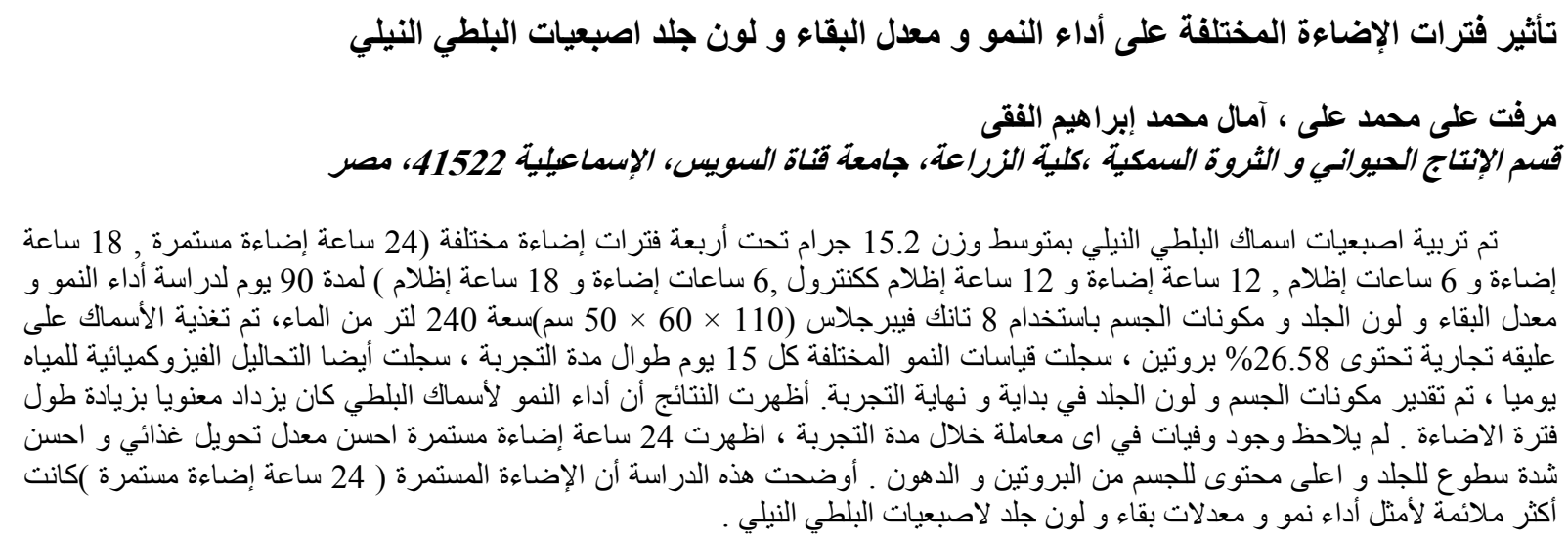

